\title{
V. Thermo-electric powers of metals and alloys between the temperatures of the boiling-point of water and the boiling-point of liquid air
}

\author{
James Dewar LL.D. F.R.S. \& J. A. Fleming M.A. D.Sc. F.R.S.
}

To cite this article: James Dewar LL.D. F.R.S. \& J. A. Fleming M.A. D.Sc. F.R.S. (1895) V. Thermoelectric powers of metals and alloys between the temperatures of the boiling-point of water and the boiling-point of liquid air , Philosophical Magazine Series 5, 40:242, 95-119, DOI: $10.1080 / 14786449508620712$

To link to this article: http://dx.doi.org/10.1080/14786449508620712

曲 Published online: 08 May 2009.

Submit your article to this journal

Ш Article views: 4

View related articles $\sqsubset$ 


\section{$\left[\begin{array}{ll}95 & ]\end{array}\right.$}

V. Thermo-electric Powers of Metals and Alloys between the Temperatures of the Boiling-Point of Water and the Boiling-Point of Liquid Air. By James Dewar, LL.D., F.R.S., Professor of Chemistry in the Royal Institution, \&c., and J. A. Fleming, M.A., D.Sc., F.R.S., Professor of Electrical Engineering in University College, London, \&c.*

[Plates III. \& IV.]

1. TF one junction of a thermo-electric couple is at a temperature $t^{\circ}$, and if the two junctions of the couple differ in temperature by a very small interval $d t$, and if the electromotive force of the couple under these conditions is $d \mathrm{E}$, then the thermo-electric power of the couple at the temperature $t^{\circ}$, denoted by $\mathrm{P}$, is defined by the relation $\mathrm{P}=\frac{d \mathrm{E}}{d t}$.

The well-known thermo-electric diagram of Professor Tait embodies the results of his own investigations on the thermoelectric powers of metals within the limits of the temperatures which can be reached by mercury thermometers and certain temperatures above this range. Starting from the facts first made known by Lord Kelvin in his classical thermodynamical researches, Professor Tait showed that on certain assumptions the curves representing thermo-electric power plotted as a function of temperature should be straight lines, and consequently that the lines of thermo-electromotive force obtained by plotting as ordinates the electromotive force in a thermo-electric circuit of two metals, one junction of which is kept at a constant temperature, whilst the temperature of the other junction is varied, should be parabolas with their axes vertical if plotted in terms of the variable temperature as abscissæ. Experiment within the abovementioned range of temperature confirmed these conjectures for a large number of thermo-couples, but led to the remarkable discovery that the thermo-electric lines of certain metals-notably of the magnetic metals, nickel and ironare, for temperatures above zero Centigrade, broken lines characterized by sudden changes of direction. This thermoelectric diagram of Professor Tait exhibits in a very elegant manner the chief thermo-electric facts, and enables the temperature of inversion to be determined by inspection.

2. Having it in our power to carry down the temperature

* Communicated by the Authors. 
of a thermo-electric junction to values in the neighbourhood of $-200^{\circ} \mathrm{C}$. by the employment of considerable quantities of boiling liquid air and liquid oxygen, we have been able to conduct an extensive investigation on the thermoelectric powers of metals at temperatures lying between this low temperature and that of the boiling-point of water ; and have been thus enabled to continue the thermo-electric diagram down to temperatures not very far removed from the absolute zero. We have accordingly been able to determine the points of electric inversion which lie between $0^{\circ} \mathrm{C}$. and $-200^{\circ} \mathrm{C}$., and to compare these observed values with those predicted by the extrapolation of the existing: thermo-electric diagram of Professor Tait obtained from observations at higher limits of temperature. 'The clief' interest, however, attaching to these investigations was the ability to determine whether, over these wide limits of low temperature, the thermo-electric lines of various metals remain straight lines, and whether any of the metals exhibit changes of thermo-electric power at low temperatures which cause their thermo-electric lines to be bent or brokenthus indicating a sudden change in the sign or magnitude of the "Thomson effect" at certain temperatures. The results of these experiments have been set out in a chart of thermoelectromotive forces of the various metals and alloys used in conjunction with pure lead as a thermo-couple, and from which all the required information can be obtained. This chart and the details of observations below provide the data for a full discussion of these questions.

3. The metals used by us in this investigation were for the most part in the form of wires, and were in many cases taken from the samples of pure metals employed by us in a series of determinations of the specific electrical resistance of metals at low temperature*. Omitting as unnecessary an account of much preliminary investigation, we proceed to describe the final experimental arrangem ents as follows:-

A large number of thermo-electric couples were prepared, each consisting of two wires of lead joined by an intermediate wire of another metal M. The lead wire was prepared by pressing pure lead into a wire $\cdot 0656$ centim. in diameter, and the other metallic wires had diameters approximately from about $\cdot 025$ to $\cdot 15$ centim., or else were used in the form of very thin narrow strips. The lead wires had a length of 50 centimetres, and the connecting wire of the metal or alloy

* See Dewar and Fleming, "The Electrical Resistance of Metals and Alloys at Temperatures approaching the Absolute Zero," Phil. Mag. September 1893, p. 271. 
M a length of about 54 centimetres. The junctions of each couple having been carefully soldered together, each wire was covered over with paraffined silk ribbon so as to insulate it, leaving only one junction exposed. A number of these thermo-couples were made up into a bundle, the sets of bare and covered junctions being bound together compactly, the bare in one group and the insulated junctions in another. In all the experiments to be described, the set of junctions which were insulated was kept at $0^{\circ} \mathrm{C}$. by being immersed in finely-crushed melting ice, kept well drained; the other set of junctions was exposed to temperatures ranging from $-200^{\circ} \mathrm{C}$. to $+100^{\circ} \mathrm{C}$. Two measurements had then to be made, viz., that of the temperature of the heated or cooled junction and also that of the electromotive force set up in the corresponding thermo-couple by the difference of temperature of the two junctions. The chief experimental difficulty encountered was that of determining the low temperature and determining it at the instant when the electromotive-force measurement of the couple was made. After long preliminary experiments necessary to overcome obstacles in the path, the successful method of dealing with the problem was found. These difficulties arose almost entirely out of the fact that for our purpose it was not sufficient to determine the thermo-electromotive force of the M-lead couple at fixed isolated temperatures, but we desired to determine it at any of the intermediate points of temperature lying within the range of three hundred degrees from $-200^{\circ} \mathrm{C}$. to $+100^{\circ} \mathrm{C}$. over which we were working. The apparatus finally constructed was based upon the employment of a platinum thermometer of particular form for measuring the temperature, and a measuring-instrument which could be changed instantly from a potentiometer into a resistance-balance.

4. In our previous researches on electric conductivity at low temperature, we fully satisfied ourselves that a wire of carefully annealed pure soft platinum can be cooled as often as necessary to the temperature of boiling liquid air or oxygen and yet return always to the same electrical resistance at a normal standard temperature.

Professor Callendar has demonstrated that this quality of the constancy of resistance of pure annealed platinum at determined temperatures renders it admirably adapted for thermometric purposes ; and Callendar and Griffiths have shown that a properly arranged platinum resistance affords the most suitable means for determining temperatures, and our own work at low temperatures has confirmed this fact. In our investigations on the electrical resistance of metals and alloys,

Phil. Mag. S. 5. Vol. 40. No. 242. July 1895. 
we gave all our temperature-measurements in platinum temperatures, as defined by one standard platinum thermometer; and all the measurements in this present thermo-electric research are given in terms of the same standard platinum thermometer, which we shall hereafter mention as our standard platinum thermometer $\mathrm{P}_{1}$.

If at any time it becomes necessary, these temperatures can be reduced to other scales of measurement.

For several reasons it was necessary to construct a platinum thermometer of special form for this thermo-electric work; and this was made as tollows :-A small cylinder or tube of copper 3.2 centim. long, and having a longitudinal hole through it 64 centim. in diameter, was wrapped round with two other half-cylinders of copper. These half-cylinders had bevelled edges. One half-cylinder was soldered to the central tube, and the other half-cylinder was insulated from the tube and from the first half-cylinder by a slip of mica. The whole was formed into a fairly true cylinder on the outside. 'Two wires of platinoid No, 18 s.T.G. and 30 centim. long were then soldered to the two insulated halfcylinders. These platinoid wires were kept apart by distancepieces of ebonite. A thin sheet of mica was then wrapped round the cylinder, and over this was wound 100 centim. of pure amealed silk-covered platinum wire. One end of this wire was soldered to one copper half-cylinder, and the other end to the second insulated half. It will thus be seen that we had a platinum wire connecting the ends of the platinoid wires but wound on a highly conducting copper cylinder, the over-all diameter of the bobbin being about a centimetre and a quarter. This wire constituted the platinum thermometer which will hereafter be spoken of as the working thermometer. A section and elevation of the thermometer is given in Pl. III. fig. 1. To the ends of the platinoid wires were soldered long stranded and well-insulated flexible copper connecting leads. A duplicate was then constructed in exactly the same manner, save that it had no platinum wire but had the two copper half-cylinders connected metallically together. The object of constructing this duplicate was to be able to eliminate from all measurements the resistance of the platinoid and copper wires forming the connectors of the platinum thermometer wire.

Our platinum thermometer consisted therefore of a platinum wire and of connecting conductors partly of platinoid and partly of stranded copper wire, and a blank or duplicate composed of a loop of an identical platinoid and copper wire. The reason for interposing the platinoid wire was as follows. As will to seen presently, our method of $p$ rocedure to obtain 
Ehil. Mas S.5. Vol 40 D III

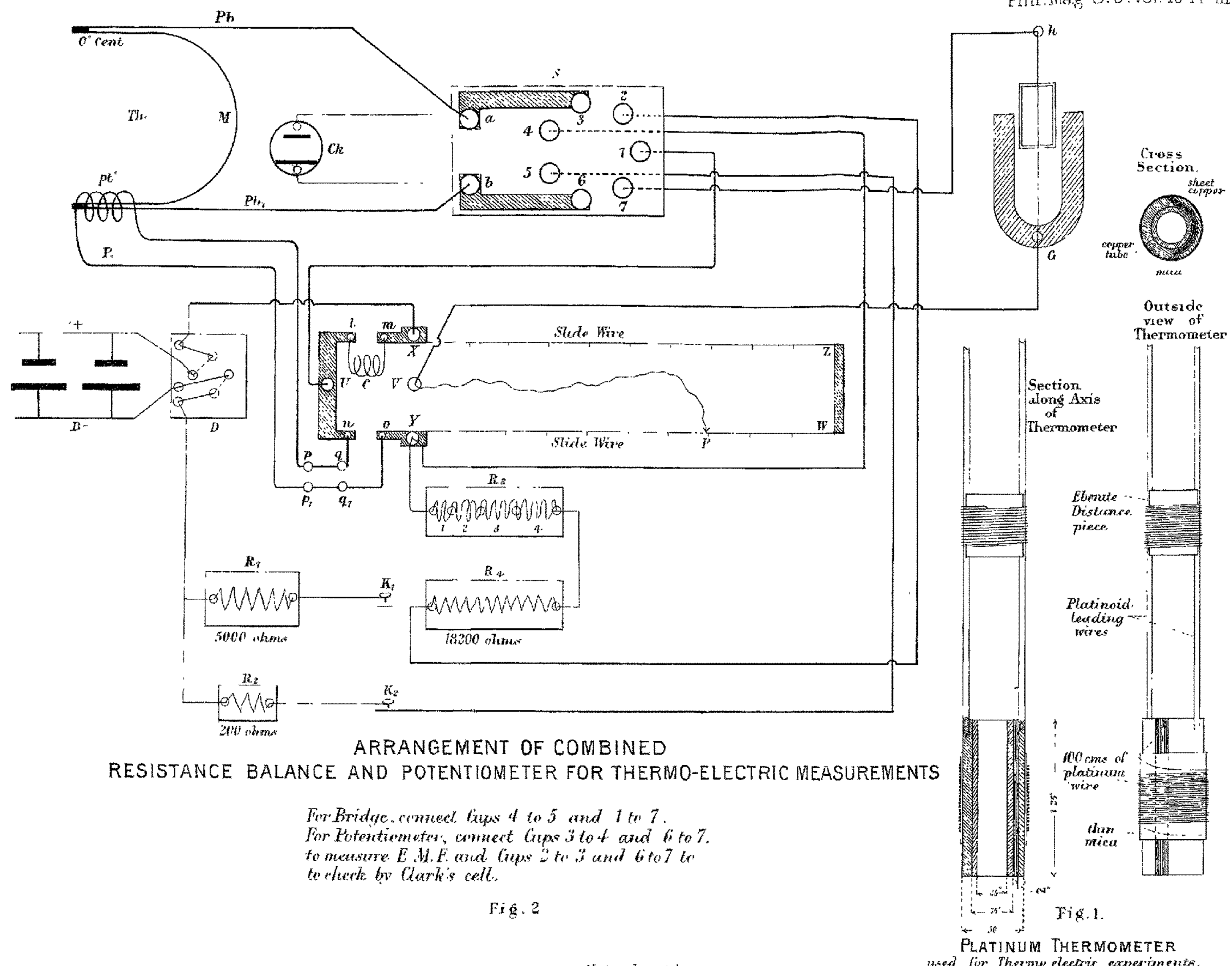


temperatures intermediate between fixed and known temperatures, such as that of the boiling-point of liquid oxygen and the mixture of solid carbonic acid and ether, was to embed the thermo-junctions in a mass of paraffin wax, and this mass having been cooled down to about $-200^{\circ}$, was allowed very slowly to heat up again.

If a platinum thermometer with copper leading-in wires is immersed in this way in paraffin wax, to determine the temperature of the junctions, then, as the thermal conductivity of the copper is greatly increased by cooling it, heat will very rapidly flow into the thermometer along the leading-in wires; and it was found by preliminary experiments quite impossible under these conditions to keep the temperature of the platinum wire used as a thermometer down to the same temperature as the thermo-junction in contact with it. By employing an alloy like platinoid of a rather high specific resistance, and by making the cross section of these platinoid leading wires relatively somewhat small, it was found possible to greatly hinder the passage of heat along the legs of the thermometer, and yet by the employment of an identical blank conducting circuit to determine the exact temperature of the platinum wire itself from its measured resistance.

Returning, then, to the construction of the thermometer, we may mention that it was constructed of a length of platinum wire given to one of us by Professor Callendar, and that this specimen was remarkable for its relatively large temperaturecoefficient. In order to determine the resistance, and therefore the temperature, of this platinum thermometer, a slide-wire bridge was constructed. A length of two metres of uniformly drawn manganin wire was stretched over a two-metre scale. This wire constituted the bridge slide-wire. It had a diameter of $\cdot 0193$ centim. (No. 36 s.w.G.) and a resistance at $15^{\circ} \mathrm{C}$. of 26.576 ohms. It was very carefully calibrated for resistance per unit of length. Over this slide-wire moved a contactmaker; and the other two arms of the bridge consisted of a coil of manganin wire wound on a small bobbin and having a resistance of $5.000 \mathrm{ohms}$ at $15^{\circ} \mathrm{C}$, and the above-described platinum thermometer or the resistance representing its leading-in wires. The battery employed with the bridge was a two-cell lithanode secondary battery, and the galvanometer a Holden-Pitkin suspended-coil galvanometer of $4 \mathrm{ohms}$ resistance. Battery- and galvanometer-keys were inserted in the circuits as usual.

The first step in the investigation consisted in determining the resistance of the platinum thermometer attached to this bridge, which we shall speak of as the working thermometer $\mathrm{P}_{2}$, at temperatures defined by our standard platinum thermo- 
meter $P_{1}$. These platinum temperatures it may be mentioned are defined as follows :-A platinum wire has its resistance determined at $0^{\circ} \mathrm{C}$. and $100^{\circ} \mathrm{C}$, , correction being made for the resistance of its own leading-in wires. A horizontal line on a chart is then taken to represent temperature on the platinum scale and ordinates are set up at distances represented by 100 divisions on this horizontal line, and these ordinates made proportional in length to the true resistance $R_{0}$ and $R_{100}$ of the standard platinum wire at $0^{\circ} \mathrm{C}$. and $100^{\circ} \mathrm{C}$. respectively. Through the summit of these ordinates a straight line is then drawn, and the point where it cuts the horizontal axis of temperature is the absolute zero of temperature by that wire. The platinum temperature of any other body, say of boiling liquid oxygen, is then obtained by measuring the resistance of the standard platinum wire immersed in this medium, and after correcting for the resistance of the leadingin wires, obtaining the true resistance $R$ of the standard wire in the liquid oxygen. On looking out on the chart the vertical ordinate, which to the selected scale represents this resistance, it will indicate by its abscissa the platinum temperature $p t$ by that thermometer of the boiling liquid oxygen. For our standard thermometer $P_{1}$ the absolute zero is $-283^{\circ} \cdot 0$ platinum degrees on the above-described scale of temperature.

The coefficients and absolute zero-points of the thermometers $\mathrm{P}_{1}$ and $\mathrm{P}_{2}$ are as follows:-

The constants of our standard platinum thermometer $P_{1}$ are:-

$R_{0}=$ resistance of platinum wire at $0^{\circ} \mathrm{C} .=3 \cdot 1059$ ohms.

$\mathrm{R}_{100}=$ resistance of platinum wire at $100^{\circ} \mathrm{C} .=4 \cdot 2034 \mathrm{ohms}$.

$\mathbf{R}=$ resistance at any platinum temperature $p t$.

$p t=$ platinum temperature as defined by the equation

$$
p t=100 \frac{\mathbf{R}-\mathbf{R}_{0}}{\mathbf{R}_{100}-\mathbf{R}} .
$$

The resistance $\mathbf{R}$ at any platinum temperature as defined by this thermometer is given by the equation

$$
\mathbf{R}=\cdot 010975(p t+283 \cdot 0) .
$$

$\alpha=$ mean temperature-coefficient between $0^{\circ} \mathrm{C}$. and $100^{\circ} \mathrm{C}$. $=\cdot 003534$.

$$
a=\frac{\mathrm{R}_{100}-\mathrm{R}_{0}}{100 \mathrm{R}_{0}} .
$$

$-\frac{1}{\alpha}=$ reciprocal of temperature-coefficient $=-283^{\circ} \cdot 0$.

The absolute zero of this wire is $-283^{\circ} .0$ in terms of its own platinum temperature. 
Thermo-electric Powers of Meials and Alloys.

The platinum temperuture $p t$ (measured from meltingpoint of ice) is obtained from $\mathrm{R}$, the resistance at $p t^{\circ}$, by the equation

$$
p t=91 \cdot 12 \mathrm{R}-283 \cdot 0 .
$$

The platinum temperature of solid carbonic acid melting in ether at $760 \mathrm{~mm}$. is -81.9 platinum degrees by this thermometer; and the platinum temperature of liquid oxygen boiling at $760 \mathrm{~mm}$. is $-196 \cdot 7$ platinum degrees by this thermometer,

The constants of our working thermometer $\mathrm{P}_{2}$ are:-

$\mathrm{R}_{0}=$ resistance at $0^{\circ} \mathrm{C} .=7.303 \mathrm{ohms}$.

$\mathrm{R}_{100}=$ resistance at $100^{\circ} \mathrm{C} .=10 \cdot 140 \mathrm{ohms}$.

$\alpha=$ mean temperature-coefficient between $0^{\circ} \mathrm{C}$. and $100^{\circ} \mathrm{C} .=\cdot 003885$.

$-\frac{1}{\alpha}=-257^{\circ} \cdot 42$.

The absolute zero of this wire is $-283^{\circ} .0$ in terms of its own platinum temperature.

Platinum temperature as measured by this thermometer is given by the equation

$$
p t=35 \cdot 25 \mathrm{R}-257 \cdot 42,
$$

where $\mathrm{R}$ is the resistance of the wire at $p t^{\circ}$.

The platinum temperature of solid carbonic acid in ether at $760 \mathrm{~mm}$. is $-81^{\circ} \cdot 3$ platinum degrees by this thermometer; and the platinum temperature of liquid oxygen boiling under 760 millim. is $-193^{\circ} \cdot 3$ platinum degrees by this thermometer.

We find that the number representing the platinum temperature of liquid oxygen boiling under $760 \mathrm{~mm}$. when taken by the working platinum thermometer $\mathrm{P}_{2}$ is not quite identical with that given by the standard platinum thermometer $P_{1}$. Into the cause of this we will not now stop to enquire, because it did not interfere at all with our use of the working thermometer $\mathbf{P}_{2}$. Having determined the resistance of the working platinum thermometer and of the standard platinum thermometer when immersed together in boiling liquid oxygen, solid carbonic acid and ether, melting ice $\left(0^{\circ} \mathrm{C}\right.$.), and boiling water $\left(100^{\circ} \mathrm{C}\right.$.), we were able to construct a curve which gave us the true platinum temperature in terms of our standard platinum thermometer $\mathrm{P}_{1}$ of the working platinum thermometer $\mathrm{P}_{2}$ when immersed in any medium which gave it a definite resistance, and hence a definite point of balance on the slidewire of the bridge. In order to shorten the labour of correcting the observations, a scale was constructed which enabled us to infer by inspection at once from the actual 
slide-wire reading the temperature of our working thermometer $\mathrm{P}_{2}$ in terms of our standard platinum thermometer $\mathrm{P}_{1}$, all corrections for connexions being included. Hence, when the working thermometer $\mathrm{P}_{2}$ is immersed in any liquid or region of sufficiently constant or slowly varying temperature, and when the position of balance of the contact on the slidewire is found so that the resistance-bridge is balanced, then we know from this scale at once the platinum temperature of the wire of our working thermometer in terms of our standard platinum thermometer. This bridge and thermometer has proved of the very greatest use, since it enables us to measure instantlv any temperatures between absolute zero and something approaching to $200^{\circ} \mathrm{C}$., which is the highest our working thermometer will bear without injury. As an instance of the degree of accuracy in temperature measurement we can obtain with this instrument, we may mention that in the neighbourhood of $-196^{\circ} .7$, which is the platinum temperature of boiling liquid oxygen, we can with ease distinguish a change of temperature of one twenty-fifth of a degree. The same degree of accuracy is not obtained at all temperatures; but the temperatures between $0^{\circ} \mathrm{C}$. and $100^{\circ} \mathrm{C}$. can be determined to within one tenth of a degree with ease.

The above arrangements therefore enabled us to instantly determine the temperature of the platinum wire of our working thermometer, and therefore, when the temperature was constant or very slowly varying, to determine the temperature of the hollow copper cylinder on which the working platinum wire was wound.

5 . The set of bare junctions of the thermo-conples prepared as described above was then inserted into the hollow interior of the little copper cylinder of the working thermometer, and kept tightly pressed against the copper by a small conical wooden peg. We satisfied ourselves by experiment that under these conditions, if the temperature of the region in which the copper cylinder was placed was constant or very slowly varying, the temperature of the platinum wire wound round the copper cylinder was the same as that of the junctions packed into the interior of the cylinder. This being the case, we had at once the means of determining the temperature of the junctions by means of one measurement, made instantly, of the resistance of the platinum wire. We have next to describe the arrangements for determining the thermoelectromotive force set up in the couples when one set of junctions was kept at $0^{\circ} \mathrm{C}$., and the other varied.

This was accomplished by the employment of a potentiometer 
arrangement (see Pl. III. fig. 2). The calibrated manganin wire used for the resistance-balance serves also as a potentiometer wire, and the same secondary battery and galvanometer by a different arrangement of connexions are employed to complete the potentiometer. A platinoid resistance of $18,200 \mathrm{ohms}$ was constructed, and also a set of four coils of manganin wire of the same diameter as the bridge wire were prepared, and the whole of these coils joined in series with the bare manganin wire stretched over the scale. These four coils had resistances respectively equal to one, two, three, and four times that of the bridge slide-wire. We then constructed an arrangement by which we could use the same slide wire either as a bridge to measure the resistance of the working platinum thermometer, and hence to determine the temperature of the junctions inside it, or to measure the electromotive force set up in the thermo-couple by balancing it against a variable standard potential-difference calibrated with reference to a Clark cell.

It was necessary to make provision for changing the bridge into a potentiometer very rapidly, and for the purpose the connexions of the different parts of the apparatus were arranged as shown in Pl. III. fig. 2, so that by one movement of a double copper connecting-piece the connexions of the apparatus could be instantly changed from a bridge to measure the temperature of the thermometer, to a potentiometer to measure the electromotive force of the thermo-couple. The whole of the electromotive-force measurements are therefore referred to a Clark cell.

The arrangement of the combined bridge and potentiometer may be described a little more in detail as follows, and will be easily understood by reference to the diagram in Pl. III.fig. 2 .

XZWY is the two-metre slide-wire having its ends attached to terminal blocks $\mathrm{X}$ and $\mathrm{Y}$. $\mathrm{B}$ is the two-cell battery which is connected through the current-reverser $D$ with the ends of the slide-wire, having interposed between one terminal and the block $Y$ either a resistance $R_{2}$ of about $200 \mathrm{ohms}$, when used as a bridge, or resistance $R_{1}, R_{4}$, and $R_{3}$ when used as a potentiometer. $R_{1}$ was a variable resistance of about or up to $5000 \mathrm{ohms} ; R_{4}$ was a resistance of $18,200 \mathrm{ohms}$; and $R_{3}$ a resistance of $10 \times 25.576 \mathrm{ohms}$ divided into four sections having ratios of $1,2,3$, and 4 in magnitude. The galvanometer $G$ was connected to terminals $U$ and $V$ when used as a bridge, and $\mathrm{P}$ was the slide contact on the wire; the other two arms consisted of the platinum thermometer $P_{1}$ joined in between $n$ and $o$ and the 5-ohm coil $C$ joined in between $l$ and $m$. When used as a potentiometer, the thermo-couple Th 
of which the electromotive force was being measured was connected in series with the galvanometer, and joined in between the slider $\mathrm{P}$ and the end of the resistance $\mathrm{R}_{4}$. In this case the fall of potential down the slide-wire was measured as usual by a Clark cell $\mathrm{Ck}$. In order to make the changes of connexion rapidly from bridge to potentiometer, a sevencup mercury switch $\mathrm{S}$ was employed, so that by shifting a pair of copper forks all the necessary changes of connexion were made instantly.

6. The operations of measurement were then as follows :-

One set of the thermo-junctions being immersed in melting ice, the working thermometer, with the other set of thermojunctions packed inside it, was placed in a small copper tube closed at the bottom end, not touching the tube, and this was filled full of melted paraffin-wax. The copper tube was then placed in a test-tube and the whole filled with melted paraffin-wax, to between the copper tube and the glass testtube. When the wax was solid, the mass containing the thermometer-wire and junctions enclosed within it was cooled down by the employment of considerable quantities of liquid air to a temperature of about $-200^{\circ}$. As soon as the temperature had become constant, the mass of paraffin was lifted out and placed in a vacuum-jacketed vessel that it might become heated up by conduction and radiation very slowly. A series of observations was then taken for each junction in rotation, measuring first the temperature of the junctions by the thermometer-wire resistance, then changing the connexions, and measuring the electromotive force of the couple, then changing back again to the bridge arrangement to get the temperature of the junction again; and so on for each couple in rotation, as the mass of paraffin slowly warmed up. In this manner a series of observations was obtained which, when reduced, gave the electromotive force of the couple in absolute C.G.S. units and the standard platinum temperature $(p t)$ of the variable junction at that instant, the other junction being kept at $0^{\circ} \mathrm{C}$. all the time.

By the employment of carbonic acid and ether and a paraffin-oil bath the series of observations for closely adjacent temperatures was continued for each thermo-couple from the boiling-point of liquid air up to the boiling-point of water. In addition to this, very careful observations were taken of the E.M.F. of all the couples at fixed stationary temperatures, such as that of the boiling-point of liquid oxygen, the meltingpoint of solid carbonic acid, the melting-point of ice, and the boiling-point of pure water, and the intermediate observations were made in some cases with the temperature of the junctions 
rising, and in some cases falling, to give assurance that the temperature of the platinum wire was the same as that of the junctions, and did not lag behind it. Satisfactory evidence was obtained that the temperature of the platinum wire did truly represent the temperature of the thermo-junction buried in the interior of the thermometer.

We were thus enabled to obtain a series of numbers for each metal, representing at defined temperatures the thermoelectromotive force of that metal against lead. Having still in our possession a small quantity of exceedingly pure lead prepared in M. Stas's laboratory which was kindly given to us by Mr. George Matthey for our previous resistance experiments, we were enabled to measure the thermo-electromotive force of a couple formed of this pure Stas's lead and the ordinary lead used by us as the associated metal for all the couples. It was thus possible to reduce all our observations of thermo-electromotive force to a statement of the electromotive force in C.G.S. units of a couple formed of a metal $\mathrm{M}$ and of chemically pure lead, one junction being at $0^{\circ} \mathrm{C}$., and the other being at a platinum temperature $p t$ as defined by our standard platinum thermometer $P_{1}$. In the following Tables the results of all the corrected observations are given, and graphically shown plotted down in the chart (see Plate IV.).

These lines of thermo-electromotive force thus found in terms of platinum temperature are in all cases curved lines. Wherever the curve has a maximum point so that its tangent becomes parallel to the line taken as the axis of temperature, the temperature at which this occurs is the neutral point of that metal or alloy with regard to lead. If at any temperature the tangents of the curves of two metals are parallel to one another, that temperature is the neutral point of those two metals with regard to each other, or is the temperature of inversion.

The diagram of thermo-electric powers can be at once obtained from that of the thermo-electromotive forces by drawing a series of lines, the ordinates of which represent to a proper scale the slope of the curves of thermo-electromotive force.

With regard to the purity of the metals employed in this research, we may mention that the samples of platinum, gold, silver, palladium, copper, tin, lead, cadmium, magnesium, nickel (Mr. Mond's nickel deposited from nickel carbonyl), zinc, and aluminium were either the same wires as were used by us in our investigation on specific resistance, or were of 


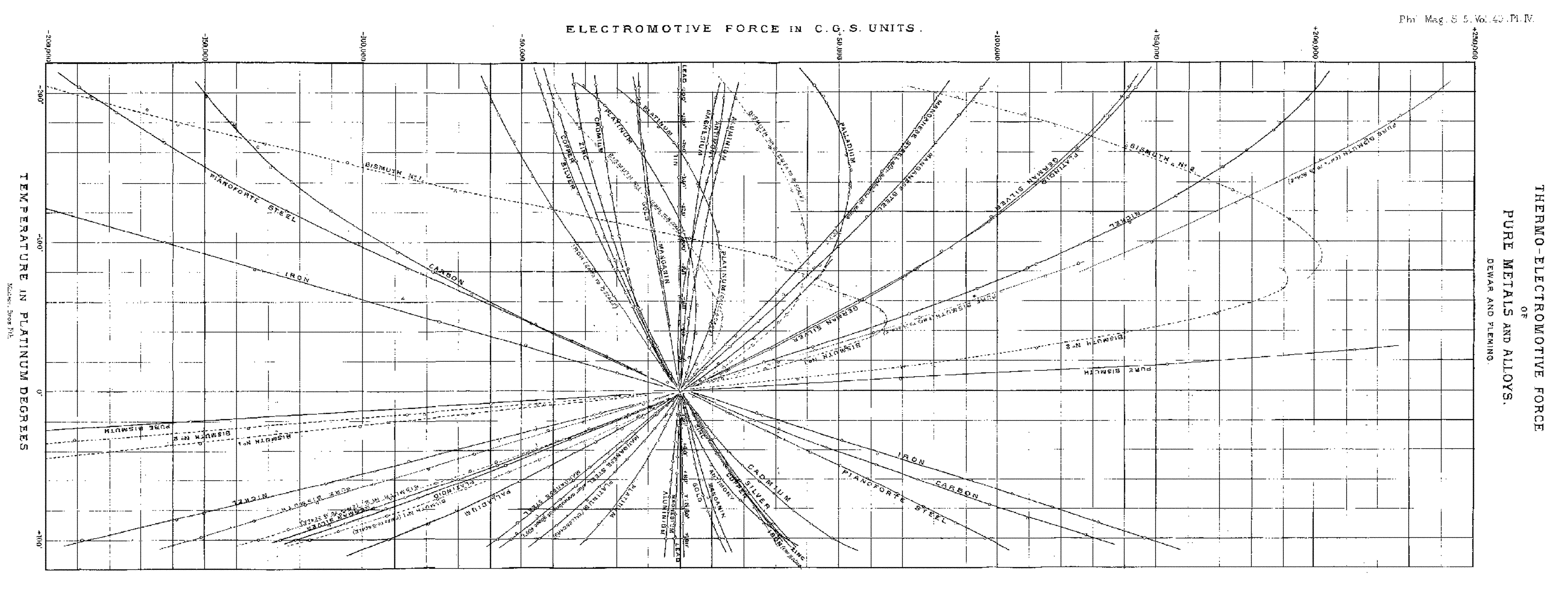


equal purity. The antimony and bismuth were prepared for us by Mr. George Matthey, to whom our thanks are especially due for valuable assistance in this matter. The other alloys used were taken as found in commerce. The iron was a sample of the softest annealed transformer iron obtainable. As regards the manganese-steel, two samples of Hadfield's 12-per-cent. manganese-steel were used, one in its ordinary non-magnetic condition, and one of the same composition brit which had been rendered sensibly magnetic by heating it to a full red-heat. It will be seen that this operation quite appreciably alters its thermo-electric value. The carbon used was a carbon filament from an incandescent lamp.

In the following Tables the values of the electromotive force of a thermo-couple formed of the metal and two chemically pure lead wires are given in C.G.S. units, as determined from a particular Clark cell, for stated temperatures. The sign + before the value of the E.M.F. signifies that the lead wire in connexion with that end of the metal which is at $0^{\circ} \mathrm{C}$. is higher in potential than the other lead wire; and the sign that the reverse is the case. The curves in the appended chart are plotted from these tables.

\section{No. 1.}

\section{Platinum-Lead Couple.}

One junction at $0^{\circ} \mathrm{C}$; t the other at $p t^{\circ}$.

\begin{tabular}{|c|c|c|c|}
\hline $\begin{array}{c}\text { E.M.F. } \\
\text { of Couple } \\
\text { in C.G.S. units. }\end{array}$ & $\begin{array}{c}\text { Temperature } p t^{\circ} \\
\text { in degrees of } \\
\text { ThandardHlatinum } \\
\text { Thermometer. }\end{array}$ & $\begin{array}{c}\text { E.M.F. } \\
\text { of Couple } \\
\text { in C.G.S. units. }\end{array}$ & $\begin{array}{c}\text { Temperature } p t^{\circ} \\
\text { in degrees of } \\
\text { Standard Platinum } \\
\text { Thermometer. }\end{array}$ \\
\hline-29630 & $+99 \cdot 9$ & +1090 & $-6 \cdot 0$ \\
-25370 & $+90 \cdot 3$ & +1530 & $-9 \cdot 8$ \\
-21920 & $+81 \cdot 2$ & +2800 & $-21 \cdot 9$ \\
-18200 & $+71 \cdot 0$ & +4530 & $-38 \cdot 9$ \\
-14670 & $+61 \cdot 1$ & +4980 & $-56 \cdot 7$ \\
-11750 & $+51 \cdot 0$ & +4750 & $-64 \cdot 9$ \\
-8910 & $+41 \cdot 7$ & +4150 & $-80 \cdot 7$ \\
-8850 & $+41 \cdot 0$ & +3520 & $-90 \cdot 2$ \\
-6830 & $+33 \cdot 2$ & +1010 & $-109 \cdot 3$ \\
-4920 & $+25 \cdot 4$ & -4150 & $-135 \cdot 1$ \\
$-\mathbf{4 7 6 0}$ & $+24 \cdot 6$ & -12040 & $-161 \cdot 1$ \\
-2830 & $+15 \cdot 6$ & -19220 & $-181 \cdot 0$ \\
-2810 & $+15 \cdot 5$ & -24690 & $-198 \cdot 8$ \\
-2050 & $+12 \cdot 3$ & -26590 & $-196 \cdot 3$ \\
-2080 & $+11 \cdot 6$ & -30930 & $-205 \cdot 6$ \\
\hline
\end{tabular}


No. 2.

Platinum-Lead Couple. (Callendar's Platinum Wire.)

One junction at $0^{\circ} \mathrm{C}$.; the other at $p t^{\circ}$.

\begin{tabular}{|c|c|c|c|}
\hline $\begin{array}{c}\text { E.M.F. } \\
\text { of Couple } \\
\text { in C.G.S. units. }\end{array}$ & $\begin{array}{c}\text { Temperature } p t^{\circ} \\
\text { in degrees of } \\
\text { Standard Platinum } \\
\text { Thermometer. }\end{array}$ & $\begin{array}{c}\text { E.M.F. } \\
\text { of Couple } \\
\text { in C.G.S. units. }\end{array}$ & $\begin{array}{l}\text { Temperature } p t^{\circ} \\
\text { in degrees of } \\
\text { StandardPlatinum } \\
\text { Thermometer. }\end{array}$ \\
\hline $\begin{array}{r}-43550 \\
-38530 \\
-34950 \\
-29320 \\
-24840 \\
-20360 \\
-16440 \\
-11550 \\
-8130 \\
-5270 \\
-4740 \\
-2650 \\
+1740 \\
+4620 \\
+7060\end{array}$ & $\begin{array}{l}+100 \cdot 2 \\
+91 \cdot 0 \\
+\quad 83 \cdot 7 \\
+73 \cdot 7 \\
+64 \cdot 3 \\
+54 \cdot 5 \\
+45 \cdot 5 \\
+34 \cdot 3 \\
+24 \cdot 7 \\
+16 \cdot 5 \\
+15 \cdot 5 \\
+9 \cdot 0 \\
+6 \cdot 4 \\
-16 \cdot 2 \\
-28 \cdot 0\end{array}$ & $\begin{array}{r}+9610 \\
+10810 \\
+11910 \\
+12370 \\
+12770 \\
+12540 \\
+11820 \\
+9090 \\
+5670 \\
+2280 \\
-1490 \\
-7470 \\
-10810 \\
-16140\end{array}$ & $\begin{array}{r}\quad 44 \cdot 1 \\
-53 \cdot 0 \\
-62.4 \\
-72 \cdot 2 \\
-81 \cdot 1 \\
-91.6 \\
-105 \cdot 8 \\
-122.9 \\
-137 \cdot 8 \\
-151.9 \\
-164.5 \\
-178.8 \\
-188 \cdot 0 \\
-195.5\end{array}$ \\
\hline
\end{tabular}

No. 3.

Gold-Lead Couple.

One junction at $0^{\circ} \mathrm{O}$; the other at $p t^{\circ}$.

\begin{tabular}{|c|c|c|c|}
\hline $\begin{array}{c}\text { E.M.F. } \\
\text { of Couple } \\
\text { in C.G.S. units. }\end{array}$ & $\begin{array}{c}\text { Temperature } p t^{\circ} \\
\text { in degrees of } \\
\text { StandardPlatinum } \\
\text { Thermometer. }\end{array}$ \\
\hline & $\begin{array}{c}\text { E.M.F. } \\
\text { of Couple }\end{array}$ & $\begin{array}{c}\text { Temperature } p t^{\circ} \\
\text { in degrees of } \\
\text { in C.G.S. units. }\end{array}$ & $\begin{array}{c}\text { Standard Platinum } \\
\text { Thermometer. }\end{array}$ \\
\hline+11600 & $+99 \cdot 9$ & -830 & $-7 \cdot 1$ \\
+10330 & $+90 \cdot 2$ & -840 & $-8 \cdot 5$ \\
+9090 & $+81 \cdot 0$ & $-20 \cdot 0$ & $-21 \cdot 3$ \\
+7670 & $+70 \cdot 8$ & -3340 & $-37 \cdot 7$ \\
+6675 & $+60 \cdot 5$ & -4970 & $-55 \cdot 8$ \\
+5380 & $+51 \cdot 0$ & -5680 & $-65 \cdot 4$ \\
+4430 & $+41 \cdot 6$ & -6940 & $-80 \cdot 8$ \\
+3820 & $+39 \cdot 9$ & -7370 & $-89 \cdot 0$ \\
+3440 & $+33 \cdot 2$ & -8690 & $-108 \cdot 1$ \\
+2340 & $+25 \cdot 1$ & -10160 & $-134 \cdot 1$ \\
+2260 & $+24 \cdot 4$ & -11560 & $-159 \cdot 8$ \\
+1510 & $+15 \cdot 8$ & -12420 & $-180 \cdot 7$ \\
+1390 & $+15 \cdot 5$ & -13020 & $-192 \cdot 7$ \\
+1360 & $+12 \cdot 3$ & -13040 & $-196 \cdot 3$ \\
+940 & +10.9 & -13420 & $-205 \cdot 4$ \\
\hline
\end{tabular}


No. 4.

Palladium-Lead Couple.

One junction at $0^{\circ} \mathrm{C}$; the other at $p t^{\circ}$.

\begin{tabular}{|c|c|c|c|}
\hline $\begin{array}{c}\text { E.M.F. } \\
\text { of Couple } \\
\text { in C.G.S. units. }\end{array}$ & $\begin{array}{l}\text { Temperature } p t^{\circ} \\
\text { in degrees of } \\
\text { Standard Platinum } \\
\text { Thermometer. }\end{array}$ & $\begin{array}{c}\text { E.M.F. } \\
\text { of Oouple } \\
\text { in O.G.S. units. }\end{array}$ & $\begin{array}{l}\text { Temperature } p t^{\circ} \\
\text { in degrees of } \\
\text { StandardPlatinum } \\
\text { Thermometer. }\end{array}$ \\
\hline $\begin{array}{l}-90920 \\
-79810 \\
-70570 \\
-59380 \\
-50220 \\
-41210 \\
-32680 \\
-29960 \\
-25680 \\
-18030 \\
-17970 \\
-11380 \\
-11200 \\
-9140 \\
-7450 \\
+5480 \\
+5610 \\
+13630 \\
+23740\end{array}$ & $\begin{array}{r}0 \\
+100 \cdot 1 \\
+90.1 \\
+80.7 \\
+70.6 \\
+60.4 \\
+51.0 \\
+41.6 \\
+38.7 \\
+33.3 \\
+24.6 \\
+24.3 \\
+15.9 \\
+15.4 \\
+12.3 \\
+10.3 \\
-\quad 7.1 \\
-\quad 7.8 \\
-21.0 \\
-36.9\end{array}$ & $\begin{array}{r}+33010 \\
+37640 \\
+43810 \\
+45730 \\
+50270 \\
+51900 \\
+53830 \\
+53980 \\
+54140 \\
+54170 \\
+54230 \\
+53840 \\
+53520 \\
+53380 \\
+52660 \\
+49360 \\
+45650 \\
+44530 \\
+41110\end{array}$ & $\begin{array}{l}0 \\
-55 \cdot 6 \\
-65 \cdot 6 \\
-80 \cdot 9 \\
-88 \cdot 0 \\
-107 \cdot 1 \\
-121 \cdot 0 \\
-132 \cdot 1 \\
-137 \cdot 4 \\
-138 \cdot 0 \\
-138 \cdot 7 \\
-139 \cdot 6 \\
-151 \cdot 0 \\
-153 \cdot 1 \\
-154 \cdot 8 \\
-158 \cdot 0 \\
-179 \cdot 6 \\
-191 \cdot 6 \\
-196.4 \\
-2050\end{array}$ \\
\hline
\end{tabular}

No. 5.

Silver-Lead Couple.

One junction at $0^{\circ} \mathrm{C}$; the other at $p t^{\circ}$.

\begin{tabular}{|c|c|c|c|}
\hline $\begin{array}{c}\text { E.M.F. } \\
\text { of Couple } \\
\text { in C.G.S. units. }\end{array}$ & $\begin{array}{c}\text { Temperature } p t^{\circ} \\
\text { in degrees of } \\
\text { Standard Platinum } \\
\text { Thermemeter. }\end{array}$ & $\begin{array}{c}\text { E.M.F } \\
\text { of Couple } \\
\text { in C.G.S. units. }\end{array}$ & $\begin{array}{c}\text { Temperature } p t^{\circ} \\
\text { in degrees of } \\
\text { StandardPlatinum } \\
\text { Thermometer. }\end{array}$ \\
\hline $\begin{array}{r}+33200 \\
+29140 \\
+26090 \\
+22100 \\
+18960 \\
+15490 \\
+12410 \\
+10970 \\
+9820 \\
+6730 \\
+6400 \\
+4460 \\
+4270 \\
+3860 \\
+2210\end{array}$ & $\begin{array}{r}+100 \cdot 1 \\
+90 \cdot 0 \\
+81 \cdot 2 \\
+70 \cdot 5 \\
+60 \cdot 6 \\
+51 \cdot 1 \\
+41 \cdot 5 \\
+38 \cdot 0 \\
+33 \cdot 3 \\
+24 \cdot 2 \\
+23 \cdot 9 \\
+16 \cdot 0 \\
+15 \cdot 4 \\
+\quad 12 \cdot 3 \\
+\quad 9.4\end{array}$ & $\begin{array}{l}2050 \\
-2650 \\
-5630 \\
-9630 \\
-14590 \\
-17580 \\
-21060 \\
-22260 \\
-26150 \\
-31250 \\
-35520 \\
-39270 \\
-41260 \\
-42060 \\
-43400\end{array}$ & $\begin{array}{r}0 \\
-\quad 6 \cdot 5 \\
-\quad 8 \cdot 5 \\
-\quad 20 \cdot 1 \\
-\quad 36 \cdot 0 \\
-\quad 54 \cdot 7 \\
-65 \cdot 9 \\
-80 \cdot 9 \\
-86 \cdot 7 \\
-105 \cdot 8 \\
-130 \cdot 6 \\
-156 \cdot 6 \\
-178 \cdot 9 \\
-190 \cdot 6 \\
-196 \cdot 4 \\
-205 \cdot 0\end{array}$ \\
\hline
\end{tabular}


No. 6.

Copper-Lead Couple.

One junction at $0^{\circ} \mathrm{C}$; the other at $p t^{\circ}$

\begin{tabular}{|c|c|c|c|}
\hline $\begin{array}{c}\text { E.M.F. } \\
\text { of Couple } \\
\text { in C.G.S. units. }\end{array}$ & $\begin{array}{l}\text { Temperature } p t^{\circ} \\
\text { in degrees of } \\
\text { StandardPlatiuum } \\
\text { Thermometer. }\end{array}$ & $\begin{array}{c}\text { E.M.F. } \\
\text { of Oouple } \\
\text { in C.G.S. units. }\end{array}$ & $\begin{array}{l}\text { Temperature } p t^{\circ} \\
\text { in degrees of } \\
\text { StandardPlatinum } \\
\text { Thermometer. }\end{array}$ \\
\hline $\begin{array}{r}+31590 \\
+27520 \\
+24500 \\
+20860 \\
+17850 \\
+14320 \\
+11540 \\
+10060 \\
+9120 \\
+6200 \\
+5780 \\
+4190 \\
+3880 \\
+3610 \\
+1985\end{array}$ & $\begin{array}{r}+100 \cdot 1 \\
+89 \cdot 9 \\
+81 \cdot 6 \\
+70 \cdot 4 \\
+61 \cdot 0 \\
+51 \cdot 6 \\
+41 \cdot 3 \\
+37 \cdot 3 \\
+33 \cdot 3 \\
+24 \cdot 1 \\
+23 \cdot 0 \\
+16 \cdot 1 \\
+15 \cdot 3 \\
+12 \cdot 3 \\
+\quad 8 \cdot 8\end{array}$ & $\begin{array}{l}-1770 \\
-\quad 2630 \\
-5070 \\
-8830 \\
-13130 \\
-15970 \\
-19240 \\
-20300 \\
-24180 \\
-28550 \\
-32980 \\
-36620 \\
-38320 \\
-40050 \\
-39920 \\
-41350\end{array}$ & $\begin{array}{r}5 \cdot 9 \\
-\quad 9 \cdot 1 \\
-\quad 19 \cdot 7 \\
-\quad 35 \cdot 2 \\
-53 \cdot 6 \\
-66.5 \\
-80 \cdot 8 \\
-85 \cdot 9 \\
-104 \cdot 7 \\
-129 \cdot 9 \\
-155 \cdot 2 \\
-178 \cdot 7 \\
-189 \cdot 9 \\
-196 \cdot 3 \\
-196 \cdot 4 \\
-205 \cdot 1\end{array}$ \\
\hline
\end{tabular}

No. 7.

Zinc-Lead Couple.

One junction at $0^{\circ} \mathrm{C}$.; the other at $p t^{\circ}$.

\begin{tabular}{|c|c|c|c|}
\hline $\begin{array}{c}\text { E.M.F. } \\
\text { of Oouple } \\
\text { in C.G.S. units. }\end{array}$ & $\begin{array}{c}\text { Temperature } p t^{\circ} \\
\text { in degrees of } \\
\text { Standard Platinum } \\
\text { Thermometer. }\end{array}$ & $\begin{array}{c}\text { E.M.F. } \\
\text { of Oouple } \\
\text { in C.G.S. units. }\end{array}$ & $\begin{array}{c}\text { Temperature } p t^{\circ} \\
\text { in degrees of } \\
\text { StandardPlatinum } \\
\text { Thermometer. }\end{array}$ \\
\hline+32390 & $\begin{array}{c}+100 \cdot 2 \\
+89 \cdot 9\end{array}$ & -810 & $-3 \cdot 3$ \\
+28060 & $+80 \cdot 4$ & -2600 & $-10 \cdot 7$ \\
+24360 & $+70 \cdot 4$ & -4500 & $-18 \cdot 4$ \\
+20920 & $+61 \cdot 1$ & -7840 & $-33 \cdot 8$ \\
+17970 & $+50 \cdot 4$ & -11700 & $-51 \cdot 9$ \\
+14100 & $+41 \cdot 2$ & -14220 & $-66 \cdot 2$ \\
+11100 & $+35 \cdot 9$ & -17130 & $-80 \cdot 6$ \\
+9260 & $+33 \cdot 2$ & -18100 & $-84 \cdot 8$ \\
+8880 & $+24 \cdot 3$ & -21140 & $-102 \cdot 9$ \\
+6180 & $+21 \cdot 4$ & -24640 & $-127 \cdot 4$ \\
+5140 & $+16 \cdot 1$ & -27540 & $-152 \cdot 1$ \\
+4270 & $+15 \cdot 3$ & -30910 & $-176 \cdot 6$ \\
+3780 & $+12 \cdot 4$ & -31900 & $-188 \cdot 4$ \\
+3450 & $+7 \cdot 5$ & -32140 & $-196 \cdot 4$ \\
+1620 & + & -33000 & $-204 \cdot 8$ \\
\hline
\end{tabular}


No. 8.

Cadmium-Lead Couple.

One junction at $0^{\circ} \mathrm{C}$; the other at $p t^{\circ}$.

\begin{tabular}{|c|c|c|c|}
$\begin{array}{c}\text { E.M.F. } \\
\text { of Couple } \\
\text { in C.G.S. units. }\end{array}$ & $\begin{array}{c}\text { Temperature } p t^{\circ} \\
\text { in degrees of } \\
\text { StandardPlatinum } \\
\text { Thermometer. }\end{array}$ & $\begin{array}{c}\text { E.M.F. } \\
\text { of Couple } \\
\text { in O.G.S. units. }\end{array}$ & $\begin{array}{c}\text { Temperature } p t^{\circ} \\
\text { in degrees of } \\
\text { StandardPlatinum } \\
\text { Thermometer. }\end{array}$ \\
\hline+48020 & $+100^{\circ} \cdot 2$ & -1180 & $-4 \cdot 0$ \\
+40940 & $+89 \cdot 9$ & -2900 & $-9 \cdot 9$ \\
+35480 & $+81 \cdot 1$ & -5120 & $-19 \cdot 1$ \\
+29370 & $+70 \cdot 3$ & -8560 & $-34 \cdot 6$ \\
+24600 & $+61 \cdot 2$ & -12140 & $-52 \cdot 6$ \\
+19380 & $+50 \cdot 6$ & -14290 & $-66 \cdot 4$ \\
+15030 & $+41 \cdot 2$ & -16350 & $-80 \cdot 7$ \\
+12810 & $+36 \cdot 6$ & -17200 & $-85 \cdot 2$ \\
+11560 & $+33 \cdot 3$ & -19340 & $-103 \cdot 8$ \\
+7920 & $+24 \cdot 1$ & -21450 & $-128 \cdot 8$ \\
+7000 & $+22 \cdot 1$ & -23410 & $-153 \cdot 8$ \\
+5160 & $+16 \cdot 1$ & -25330 & $-178 \cdot 0$ \\
+4680 & $+15 \cdot 3$ & -26090 & $-189 \cdot 1$ \\
+4330 & $+12 \cdot 4$ & -26460 & $-196 \cdot 4$ \\
+2220 & $+8 \cdot 1$ & -26940 & $-205 \cdot 0$ \\
\hline
\end{tabular}

No. 9.

Magnesium-Lead Couple.

One junction at $0^{\circ} \mathrm{C}$; the other at $p t^{\circ}$.

\begin{tabular}{|c|c|c|c|}
\hline $\begin{array}{c}\text { E.M.F. } \\
\text { of Couple } \\
\text { in C.G.S. units. }\end{array}$ & $\begin{array}{c}\text { Temperature } p t^{\circ} \\
\text { in degrees of } \\
\text { Standard Platinum } \\
\text { Thermometer. }\end{array}$ & $\begin{array}{c}\text { E.M.F. } \\
\text { of Couple } \\
\text { in C.G.S. units. }\end{array}$ & $\begin{array}{l}\text { Temperature } p t^{\circ} \\
\text { in degrees of } \\
\text { StandardPlatinum } \\
\text { Thermometer. }\end{array}$ \\
\hline $\begin{array}{l}-1260 \\
-1210 \\
-1150 \\
-960 \\
=800 \\
-760 \\
-780 \\
=610 \\
=340 \\
=190 \\
=190 \\
-230 \\
+60 \\
+280 \\
+600\end{array}$ & 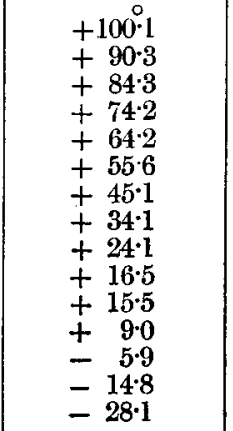 & $\begin{array}{l}+1110 \\
+1310 \\
+1830 \\
+\quad 2160 \\
+2530 \\
+3180 \\
+3900 \\
+4910 \\
+5910 \\
+7160 \\
+8210 \\
+9430 \\
+9990 \\
+11330\end{array}$ & $\begin{array}{l}\quad 44 \cdot 8 \\
-53 \cdot 5 \\
-63 \cdot 2 \\
-72 \cdot 4 \\
-81 \cdot 1 \\
-89 \cdot 6 \\
-104 \cdot 2 \\
-121 \cdot 2 \\
-136 \cdot 4 \\
-152 \cdot 7 \\
-165 \cdot 7 \\
-178 \cdot 7 \\
-183 \cdot 8 \\
-195 \cdot 5\end{array}$ \\
\hline
\end{tabular}


No. 10.

Tin-Lead Couple.

One junotion at $0^{\circ} \mathrm{O}$; the other at $p t^{\circ}$.

\begin{tabular}{|c|c|c|c|}
\hline $\begin{array}{c}\text { E.M.F. } \\
\text { of Couple } \\
\text { in C.G.S. units. }\end{array}$ & $\begin{array}{l}\text { Temperature } p t^{\circ} \\
\text { in degrees of } \\
\text { Standard Platinum } \\
\text { Thermometer. }\end{array}$ & $\begin{array}{c}\text { E.M.F. } \\
\text { of Couple } \\
\text { in C.G.S. units. }\end{array}$ & $\begin{array}{l}\text { Temperature } p t^{\circ} \\
\text { in degrees of } \\
\text { Standard Platinum } \\
\text { Thermometer. }\end{array}$ \\
\hline $\begin{array}{l}+570 \\
+460 \\
+410 \\
+360 \\
+340 \\
+340 \\
+270 \\
+190 \\
+200 \\
+140 \\
+150 \\
+90 \\
+80 \\
+50 \\
+70\end{array}$ & $\begin{array}{r}+100 \cdot 1 \\
+89 \cdot 9 \\
+79 \cdot 4 \\
+70 \cdot 1 \\
+60 \cdot 7 \\
+50 \cdot 5 \\
+41 \cdot 2 \\
+33 \cdot 6 \\
+33 \cdot 1 \\
+25 \cdot 2 \\
+19 \cdot 6 \\
+16 \cdot 2 \\
+15 \cdot 2 \\
+12.4 \\
+6.1\end{array}$ & $\begin{array}{r}0 \\
-\quad 80 \\
-\quad 50 \\
-140 \\
-150 \\
-240 \\
-290 \\
-220 \\
-260 \\
-360 \\
-340 \\
-440 \\
-430 \\
-490 \\
-440\end{array}$ & $\begin{aligned} & 20 \\
&= 2.0 \\
&= 11.7 \\
&- 16.7 \\
&- 31.6 \\
&- 48.7 \\
&- 64.2 \\
&- 80.8 \\
&- 81.8 \\
&-100.9 \\
&-124.2 \\
&-147.8 \\
&-168.6 \\
&-185.8 \\
&-1964 \\
&-203.8\end{aligned}$ \\
\hline
\end{tabular}

No. 11.

Iron-Lead Couple.

One junction at $0^{\circ} \mathrm{C}$; the other at $p t^{\circ}$.

\begin{tabular}{|c|c|c|c|}
\hline $\begin{array}{c}\text { E.M.F. } \\
\text { of Couple } \\
\text { in C.G.S. units. }\end{array}$ & $\begin{array}{l}\text { Temperature } p t^{\circ} \\
\text { in degrees of } \\
\text { Standard Platinum } \\
\text { Thermometer. }\end{array}$ & $\begin{array}{c}\text { E.M.F. } \\
\text { of Oouple } \\
\text { in C.G.S. units. }\end{array}$ & $\begin{array}{l}\text { Temperature } p t^{\circ} \\
\text { in degrees of } \\
\text { Standard Platinum } \\
\text { Thermometer. }\end{array}$ \\
\hline $\begin{array}{r}+145360 \\
+132110 \\
+117540 \\
+104830 \\
+91940 \\
+77150 \\
+61930 \\
+50780 \\
+47990 \\
+39180 \\
+27680 \\
+24380 \\
+23300 \\
+20870 \\
+\quad 7120\end{array}$ & $\begin{array}{l}+100.1 \\
+89 \cdot 9 \\
+79 \cdot 2 \\
+69 \cdot 9 \\
+60 \cdot 4 \\
+50 \cdot 8 \\
+41 \cdot 3 \\
+33 \cdot 1 \\
+32 \cdot 5 \\
+25 \cdot 9 \\
+19 \cdot 0 \\
+16 \cdot 3 \\
+15.2 \\
+12.4 \\
+5.5\end{array}$ & $\begin{array}{l}-2840 \\
-\quad 20030 \\
-26240 \\
-49090 \\
=76050 \\
=104190 \\
=131940 \\
=134250 \\
=163590 \\
-201010 \\
-235730 \\
-264340 \\
-286090 \\
-298860 \\
-305400\end{array}$ & 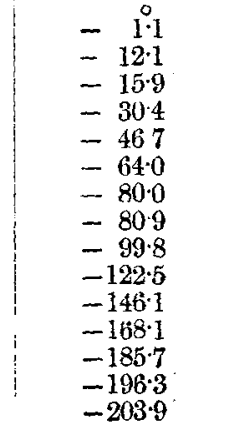 \\
\hline
\end{tabular}


No. 12.

Nickel-Lead Couple.

One junction at $0^{\circ} \mathrm{C}$; the other at $p t^{\circ}$.

\begin{tabular}{|c|c|c|c|}
\hline $\begin{array}{c}\text { E.M.F. } \\
\text { of Couple } \\
\text { in C.G.S. units. }\end{array}$ & $\begin{array}{l}\text { Temperature } p t^{\circ} \\
\text { in degrees of } \\
\text { Standard Platinum } \\
\text { Thermometer. }\end{array}$ & $\begin{array}{c}\text { E.M.F. } \\
\text { of Couple } \\
\text { in C.G.S. units. }\end{array}$ & $\begin{array}{l}\text { Temperature } p t^{\circ} \\
\text { in degrees of } \\
\text { Standard Platinum } \\
\text { Thermometer. }\end{array}$ \\
\hline $\begin{array}{l}-188860 \\
-158380 \\
-150070 \\
-130890 \\
-110810 \\
-95400 \\
-85430 \\
-57140 \\
-45770 \\
-26740 \\
-25530 \\
-14790 \\
+14110 \\
+27570 \\
+42520\end{array}$ & $\begin{array}{r}+100 \cdot 1 \\
+86 \cdot 3 \\
+82 \cdot 1 \\
+72 \cdot 8 \\
+62 \cdot 6 \\
+54 \cdot 5 \\
+49 \cdot 2 \\
+33 \cdot 8 \\
+27 \cdot 1 \\
+16 \cdot 5 \\
+15 \cdot 7 \\
+\quad 9 \cdot 2 \\
+\quad 9 \cdot 0 \\
-\quad 18 \cdot 3 \\
-\quad 28.5\end{array}$ & $\begin{array}{l}+60180 \\
+72990 \\
+\quad 84190 \\
+\quad 94230 \\
+109470 \\
+112400 \\
+126290 \\
+141470 \\
+156090 \\
+171260 \\
+178190 \\
+187180 \\
+189730 \\
+198040\end{array}$ & $\begin{array}{l}-41 \cdot 1 \\
-50 \cdot 1 \\
-59 \cdot 1 \\
-67 \cdot 0 \\
-80 \cdot 9 \\
-83 \cdot 8 \\
-97 \cdot 6 \\
-112 \cdot 9 \\
-130 \cdot 0 \\
-149 \cdot 7 \\
-160 \cdot 7 \\
-175 \cdot 9 \\
-181 \cdot 5 \\
-195 \cdot 5\end{array}$ \\
\hline
\end{tabular}

No. 13.

Pianoforte Steel-Lead Couple.

One junction at $0^{\circ} \mathrm{C}$; the other at $p t^{\circ}$.

\begin{tabular}{|c|c|c|c|}
\hline $\begin{array}{c}\text { E.M.F. } \\
\text { of Couple } \\
\text { in C.G.S. units. }\end{array}$ & $\begin{array}{c}\text { Temperature } p t^{\circ} \\
\text { in degrees of } \\
\text { StandardPlatinum } \\
\text { Thermometer. }\end{array}$ & $\begin{array}{c}\text { E.M.F. } \\
\text { of Couple } \\
\text { in C.G.S. units. }\end{array}$ & $\begin{array}{c}\text { Temperature } p t^{\circ} \\
\text { in degrees of } \\
\text { Standard Platinum } \\
\text { Thermometer. }\end{array}$ \\
\hline+96030 & $+100 \cdot 1$ & -1460 & $-0 \cdot 8$ \\
+87140 & $+89 \cdot 9$ & -12920 & $-12 \cdot 2$ \\
+77200 & $+79 \cdot 1$ & -16100 & $-15 \cdot 3$ \\
+68730 & $+70 \cdot 3$ & -30680 & $-29 \cdot 6$ \\
+59260 & $+60 \cdot 2$ & -47310 & $-46 \cdot 0$ \\
+50250 & $+50 \cdot 8$ & -65250 & $-63 \cdot 7$ \\
+40480 & $+41 \cdot 2$ & -81810 & $-79 \cdot 3$ \\
+32890 & $+33 \cdot 0$ & -84660 & $-80 \cdot 8$ \\
+30290 & $+31 \cdot 8$ & -101240 & $-98 \cdot 7$ \\
+26040 & $+26 \cdot 2$ & -124030 & $-120 \cdot 5$ \\
+17330 & $+18 \cdot 4$ & -145180 & $-144 \cdot 6$ \\
+15900 & $+16 \cdot 3$ & -163340 & $-167 \cdot 1$ \\
+15000 & $+15 \cdot 2$ & -177260 & $-185 \cdot 6$ \\
+13310 & $+12 \cdot 4$ & -184770 & $-196 \cdot 3$ \\
+4220 & $+5 \cdot 1$ & -189650 & $-204 \cdot 0$ \\
\hline
\end{tabular}


No. 14.

Hadfield's Manganese Steel-Lead Couple. (Non-Magnetic.)

One junction at $0^{\circ} \mathrm{C}$; the other at $p t^{\circ}$.

\begin{tabular}{|c|c|c|c|}
\hline $\begin{array}{c}\text { E.M.F. } \\
\text { of Couple } \\
\text { in C.G.S. units. }\end{array}$ & $\begin{array}{c}\text { Temperature } p t^{\circ} \\
\text { in degrees of } \\
\text { Standard Platinum } \\
\text { Thermoneter. }\end{array}$ & $\begin{array}{c}\text { E.M.F. } \\
\text { of Couple } \\
\text { in C.G.S, units. }\end{array}$ & $\begin{array}{l}\text { Temperature } p t^{\circ} \\
\text { in degrees of } \\
\text { Standard Platinum } \\
\text { Thermometer. }\end{array}$ \\
\hline $\begin{array}{l}-57360 \\
-51120 \\
-44700 \\
-40320 \\
-33280 \\
-27870 \\
-22190 \\
-17930 \\
-16570 \\
-14290 \\
-9040 \\
-8730 \\
-8050 \\
-6840 \\
-2410\end{array}$ & $\begin{array}{r}+100 \cdot 1 \\
+\quad 89 \cdot 9 \\
+79 \cdot 1 \\
+71 \cdot 3 \\
+60 \cdot 1 \\
+50 \cdot 7 \\
+41 \cdot 2 \\
+33 \cdot 0 \\
+\quad 31 \cdot 1 \\
+\quad 26 \cdot 2 \\
+17 \cdot 9 \\
+16 \cdot 4 \\
+\quad 15 \cdot 2 \\
+\quad 12 \cdot 5 \\
+\quad 4 \cdot 9\end{array}$ & $\begin{array}{l}+320 \\
+\quad 6700 \\
+\quad 8060 \\
+15360 \\
+23840 \\
+32260 \\
+40590 \\
+42300 \\
+49850 \\
+58960 \\
+71] 10 \\
+80480 \\
+88100 \\
+92770 \\
+95260\end{array}$ & 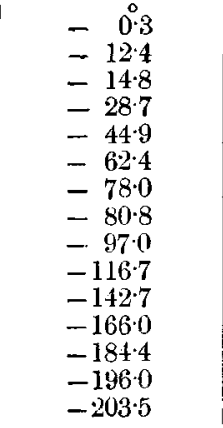 \\
\hline
\end{tabular}

No. 15.

Hadfield's Manganese Steel-Load Couple. (Magnetic.)

One junction at $0^{\circ} \mathrm{C}$.; the other at $p t^{\circ}$.

\begin{tabular}{|c|c|c|c|}
\hline $\begin{array}{c}\text { E.M.F. } \\
\text { of Couple } \\
\text { in C.G.S. units. }\end{array}$ & $\begin{array}{c}\text { Temperature } p t^{\circ} \\
\text { in degrees of } \\
\text { StandardPlatinum } \\
\text { Tbermometer. }\end{array}$ & $\begin{array}{c}\text { E.M.F. } \\
\text { of Couple } \\
\text { in C.G.S. units. }\end{array}$ & $\begin{array}{c}\text { Temperature } p t^{\circ} \\
\text { in degrees of } \\
\text { Standard Platinum } \\
\text { Thermometer. }\end{array}$ \\
\hline $\begin{array}{l}-52190 \\
-51160 \\
-42360 \\
-36860 \\
-32290 \\
-26950 \\
-24160 \\
-17150 \\
-13900 \\
-8040 \\
-7840 \\
-4720 \\
+4240 \\
+9350 \\
+13610\end{array}$ & $\begin{array}{r}+100.0 \\
+\quad 96.9 \\
+82.9 \\
+72.6 \\
+63.3 \\
+53.2 \\
+47.8 \\
+34.3 \\
+27.3 \\
+16.4 \\
+16.0 \\
+\quad 9.4 \\
+\quad 9.7 \\
-20.7 \\
-\quad 29.5\end{array}$ & $\begin{array}{r}+17570 \\
+22580 \\
+27360 \\
+30190 \\
+36900 \\
+37740 \\
+42980 \\
+49190 \\
+56440 \\
+64170 \\
+68330 \\
+74680 \\
+77500 \\
+81680\end{array}$ & $\begin{array}{l}3.2 \\
-\quad 49.0 \\
-59 \cdot 6 \\
-65.5 \\
-80.0 \\
-81 \cdot 1 \\
-94 \cdot 1 \\
-108 \cdot 7 \\
-127.0 \\
-147.0 \\
-157.2 \\
-174.0 \\
-182.0 \\
-195.5\end{array}$ \\
\hline
\end{tabular}

Phil. Mag. S. 5. Vol. 40. No. 242. July $1895 . \quad$ I 
No. 16. Manganin-Lead Couple.

One junction at $0^{\circ} \mathrm{C}$; the other at $p t^{\circ}$.

\begin{tabular}{|c|c|c|c|}
\hline $\begin{array}{c}\text { E.M.F. } \\
\text { of Couple } \\
\text { in C.G.S. units. }\end{array}$ & $\begin{array}{l}\text { Temperature } p t^{\circ} \\
\text { in degrees of } \\
\text { Standard Platinum } \\
\text { Thermometer. }\end{array}$ & $\begin{array}{c}\text { E.M.E. } \\
\text { of Couple } \\
\text { in C.G.S. units. }\end{array}$ & $\begin{array}{l}\text { Temperature } p t^{\circ} \\
\text { in degrees of } \\
\text { Standard Platinum } \\
\text { Thermometer. }\end{array}$ \\
\hline $\begin{array}{r}+13770 \\
+12220 \\
+11000 \\
+9200 \\
+7520 \\
+6300 \\
+5240 \\
+4080 \\
+3130 \\
+3115 \\
+1760 \\
+1670 \\
+1750 \\
+\quad 2070 \\
+\quad 550 \\
+\quad 290 \\
-1010 \\
-1060 \\
-2510 \\
-3460 \\
-3790 \\
-3790 \\
-4320 \\
-4660 \\
-5320\end{array}$ & $\begin{array}{l}+100 \cdot 1 \\
+89 \cdot 9 \\
+79 \cdot 7 \\
+72 \cdot 1 \\
+60 \cdot 1 \\
+505 \\
+41 \cdot 2 \\
+32 \cdot 7 \\
+29 \cdot 1 \\
+26 \cdot 2 \\
+16 \cdot 5 \\
+16 \cdot 1 \\
+15 \cdot 3 \\
+12 \cdot 6 \\
+3 \cdot 9 \\
+1 \cdot 1 \\
+12 \cdot 7 \\
-13 \cdot 0 \\
-26 \cdot 4 \\
-41 \cdot 0 \\
-42 \cdot 4 \\
-44 \cdot 5 \\
-54 \cdot 1 \\
-57 \cdot 7 \\
-60 \cdot 2\end{array}$ & $\begin{array}{l}-4950 \\
-5200 \\
-5600 \\
-5830 \\
-5900 \\
-5850 \\
-6350 \\
-6210 \\
-6360 \\
-6570 \\
-6560 \\
=6670 \\
=7150 \\
=7190 \\
-7450 \\
=7690 \\
-8000 \\
-8550 \\
-8540 \\
-10010 \\
-11040 \\
-12850 \\
-13490 \\
-14130\end{array}$ & $\begin{array}{l}-60 \cdot 9 \\
-64 \cdot 1 \\
-68 \cdot 0 \\
-72 \cdot 6 \\
-74 \cdot 1 \\
-76 \cdot 2 \\
-78 \cdot 0 \\
-80 \cdot 7 \\
-81 \cdot 7 \\
-83 \cdot 5 \\
-85 \cdot 7 \\
-88.6 \\
-92 \cdot 9 \\
-930 \\
-99 \cdot 4 \\
-105 \cdot 4 \\
-110 \cdot 4 \\
-112 \cdot 2 \\
-137.5 \\
-160 \cdot 4 \\
-182.5 \\
-196.2 \\
-203 \cdot 1\end{array}$ \\
\hline
\end{tabular}

No. 17. German Silver-Lead Couple.

One junction at $0^{\circ} \mathrm{C}$; the other at $p t^{\circ}$.

\begin{tabular}{|c|c|c|c|}
\hline $\begin{array}{c}\text { E.M.F. } \\
\text { of Couple } \\
\text { in C.G.S. units. }\end{array}$ & $\begin{array}{c}\text { T'emperature } p t^{\circ} \\
\text { in degrees of } \\
\text { Standard Platinum } \\
\text { Thermometer. }\end{array}$ & $\begin{array}{c}\text { E.M.F. } \\
\text { of Couple } \\
\text { in C.G.S. units. }\end{array}$ & $\begin{array}{c}\text { Teinperature } p t^{\circ} \\
\text { in degrees of } \\
\text { StandardPlatinum } \\
\text { Therwometer. }\end{array}$ \\
\hline $\begin{array}{l}-125050 \\
-110490 \\
-\quad 95650 \\
-\quad 85890 \\
=\quad 69920 \\
=57530 \\
=\quad 45940 \\
=36440 \\
=32260 \\
=28820 \\
=17810 \\
=17340 \\
=16220 \\
=13570 \\
-\quad 3910\end{array}$ & $\begin{array}{l}+100 \cdot 1 \\
+\quad 89 \cdot 9 \\
+79 \cdot 2 \\
+72 \cdot 0 \\
+\quad 60 \cdot 0 \\
+50 \cdot 6 \\
+41 \cdot 2 \\
+32 \cdot 9 \\
+30 \cdot 4 \\
+26 \cdot 2 \\
+17 \cdot 1 \\
+16 \cdot 4 \\
+15 \cdot 2 \\
+12 \cdot 5 \\
+\quad 4 \cdot 5\end{array}$ & $\begin{array}{l}+\quad 320 \\
+\quad 13070 \\
+14790 \\
+28390 \\
+43170 \\
+58180 \\
+70910 \\
+74030 \\
+85250 \\
+97580 \\
+113170 \\
+124670 \\
+133830 \\
+139270 \\
+139540 \\
+141950\end{array}$ & 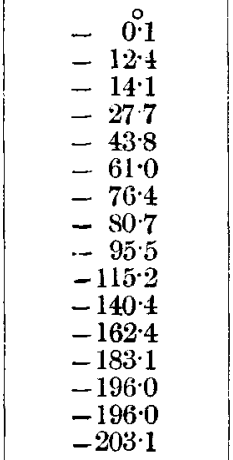 \\
\hline
\end{tabular}


No. 18.

Platinoid-Lead Couple.

One junction at $0^{\circ} \mathrm{O}$.; the other at $p t^{\circ}$.

\begin{tabular}{|c|c|c|c|}
\hline $\begin{array}{c}\text { E.M.F. } \\
\text { of Couple } \\
\text { in C.Ǵ.S. units. }\end{array}$ & $\begin{array}{l}\text { Temperature } p t^{\circ} \\
\text { in degrees of } \\
\text { Standard Platinum } \\
\text { Thermometer. }\end{array}$ & $\begin{array}{c}\text { E.M.F. } \\
\text { of Couple } \\
\text { in C.G.S. units. }\end{array}$ & $\begin{array}{c}\text { Temperature } p t^{\circ} \\
\text { in degrees of } \\
\text { Standard Platinum } \\
\text { Thermometer. }\end{array}$ \\
\hline $\begin{array}{l}-120250 \\
-105970 \\
-92550 \\
-82620 \\
-66570 \\
-54690 \\
-44080 \\
-34720 \\
-30680 \\
-\quad 27710 \\
-15850 \\
-16690 \\
-15540 \\
-12940 \\
-\quad 3500\end{array}$ & $\begin{array}{r}+100^{\circ} \cdot 1 \\
+899 \\
+79 \cdot 4 \\
+72 \cdot 2 \\
+60 \cdot 0 \\
+50 \cdot 5 \\
+41 \cdot 2 \\
+32 \cdot 8 \\
+29 \cdot 8 \\
+26 \cdot 2 \\
+16 \cdot 6 \\
+16 \cdot 5 \\
+15 \cdot 3 \\
+12 \cdot 5 \\
+\quad 4 \cdot 2\end{array}$ & $\begin{array}{r}+\quad 30 \\
+\quad 13290 \\
+14230 \\
+\quad 27200 \\
+41680 \\
+\quad 57060 \\
+69980 \\
+73810 \\
+\quad 83450 \\
+\quad 96950 \\
+112560 \\
+135160 \\
+134770 \\
+141120 \\
+143760\end{array}$ & $\begin{array}{l}0 \\
-\quad 0.5 \\
-\quad 19.6 \\
-13.4 \\
-26.9 \\
-429 \\
-60.4 \\
-75 \cdot 1 \\
-80.7 \\
-939 \\
-113 \cdot 1 \\
-1386 \\
-161 \cdot 0 \\
-182.7 \\
-196 \cdot 0 \\
-2029\end{array}$ \\
\hline
\end{tabular}

No. 19.

(Pure) Bismuth-Lead Couple.

One junction at $0^{\circ} \mathrm{C}$; the other at $p t^{\circ}$.

\begin{tabular}{|c|c|c|c|}
\hline $\begin{array}{c}\text { E.M.F. } \\
\text { of Couple } \\
\text { in C.G.S. units. }\end{array}$ & $\begin{array}{c}\text { Temperature } p t^{\circ} \\
\text { in degrees of } \\
\text { Standard Platinum } \\
\text { Thermometer. }\end{array}$ & $\begin{array}{c}\text { E.M.F. } \\
\text { of Couple } \\
\text { in C.G.S. units. }\end{array}$ & $\begin{array}{l}\text { Temperature } p t^{\circ} \\
\text { in deyrees of } \\
\text { StandardPlatinum } \\
\text { Thermometer. }\end{array}$ \\
\hline $\begin{array}{r}-754480 \\
-673080 \\
-590550 \\
-573490 \\
-479360 \\
-398360 \\
-317540 \\
-208380 \\
-153740 \\
-59940 \\
+69530 \\
+153990 \\
+212970\end{array}$ & $\begin{array}{r}+98.1 \\
+87.2 \\
+75.9 \\
+74.6 \\
+60.9 \\
+50.7 \\
+40.0 \\
+26.1 \\
+20.1 \\
+8.5 \\
-7.5 \\
-18.5 \\
-26.5\end{array}$ & $\begin{array}{r}+301840 \\
+379590 \\
+506570 \\
+578310 \\
+623330 \\
+744280 \\
+869260 \\
+952840 \\
+1006770 \\
+1074700 \\
+1125800 \\
+1178210\end{array}$ & $\begin{array}{l}-38 \cdot 5 \\
-49 \cdot 0 \\
-65 \cdot 6 \\
-77 \cdot 2 \\
-83 \cdot 7 \\
-99 \cdot 1 \\
-122 \cdot 2 \\
-140 \cdot 1 \\
-15 \cdot 0 \\
-165 \cdot 1 \\
-181 \cdot 6 \\
-195 \cdot 7\end{array}$ \\
\hline
\end{tabular}


No. 20.

(Commercial) Bismuth-Lead Couple. (No. 1.)

One junction at $0^{\circ} \mathrm{C}$; the other at $p t^{\circ}$.

\begin{tabular}{|c|c|c|c|}
\hline $\begin{array}{c}\text { E.M.F. } \\
\text { of Couple } \\
\text { in C.G.S. units. }\end{array}$ & $\begin{array}{c}\text { Temperature } p t^{\circ} \\
\text { in degrees of } \\
\text { StandardPlatinum } \\
\text { Thermometer. }\end{array}$ & $\begin{array}{c}\text { E.M.F. } \\
\text { of Couple } \\
\text { in C.G.S. units. }\end{array}$ & $\begin{array}{l}\text { Temperature pt } \\
\text { in degrees of } \\
\text { StandardPlatinum } \\
\text { Thermometer. }\end{array}$ \\
\hline $\begin{array}{l}-579100 \\
-539720 \\
-458330 \\
-388860 \\
-334700 \\
-272930 \\
-212460 \\
-152140 \\
-100400 \\
-66460 \\
-64720 \\
-43120 \\
-40720 \\
+11870 \\
+27780 \\
+53090\end{array}$ & $\begin{array}{l}+100 \cdot 1 \\
+94 \cdot 3 \\
+84 \cdot 0 \\
+74 \cdot 0 \\
+66 \cdot 3 \\
+55 \cdot 9 \\
+46 \cdot 2 \\
+34 \cdot 2 \\
+24 \cdot 1 \\
+16 \cdot 5 \\
+15 \cdot 6 \\
+9 \cdot 8 \\
+9 \cdot 1 \\
=7 \cdot 0 \\
=14 \cdot 8 \\
-28.5\end{array}$ & $\begin{array}{l}+64580 \\
+63600 \\
\text { Balancing posi } \\
+52480 \\
\text { Balancing posi } \\
+47810 \\
+33120 \\
+29640 \\
+2700 \\
-35570 \\
-70960 \\
-105760 \\
-130870 \\
-159240 \\
-167740 \\
-187370\end{array}$ & $\begin{array}{r}-44 \cdot 4 \\
-52 \cdot 1 \\
\text { tion variable. } \\
-64 \cdot 2 \\
\text { tion variable. } \\
-70 \cdot 8 \\
-81 \cdot 0 \\
-87 \cdot 9 \\
-102 \cdot 2 \\
-119 \cdot 5 \\
-135 \cdot 2 \\
-153.3 \\
-165 \cdot 3 \\
-178 \cdot 7 \\
-186 \cdot 9 \\
-195 \cdot 5\end{array}$ \\
\hline
\end{tabular}

No. 21.

(Commercial) Bismuth-Lead Couple. (No. 2.)

One junction at $0^{\circ} \mathrm{C}$; the other at $p t^{\circ}$.

\begin{tabular}{|c|c|c|c|}
\hline $\begin{array}{c}\text { E.M.F. } \\
\text { of Couple } \\
\text { in C.G.S. units. }\end{array}$ & $\begin{array}{c}\text { Temperature } p t^{\epsilon} \\
\text { in degrees of } \\
\text { Standard Platinum } \\
\text { Thermometer. }\end{array}$ & $\begin{array}{c}\text { E.M.F. } \\
\text { of Couple } \\
\text { in C.G.S. units. }\end{array}$ & $\begin{array}{c}\text { Temperature } p t^{\circ} \\
\text { in degrees of } \\
\text { StandardPlatinum } \\
\text { Thermometer. }\end{array}$ \\
\hline $\begin{array}{r}-664150 \\
-612480 \\
-533680 \\
-457460 \\
-388400 \\
-329450 \\
-287060 \\
-191070 \\
-136130 \\
-86090 \\
-80600 \\
-\quad 47690 \\
-45050 \\
+\quad 37150 \\
+70020\end{array}$ & $\begin{array}{r}+100^{\circ} \cdot 0 \\
+92 \cdot 4 \\
+83 \cdot 0 \\
+73 \cdot 2 \\
+63 \cdot 2 \\
+55 \cdot 0 \\
+48 \cdot 8 \\
+33 \cdot 9 \\
+25 \cdot 9 \\
+16 \cdot 5 \\
+15 \cdot 6 \\
+9 \cdot 7 \\
+9 \cdot 1 \\
+8 \cdot 2 \\
-16.2\end{array}$ & $\begin{array}{r}+113070 \\
+153140 \\
+168800 \\
+184340 \\
+189780 \\
+190120 \\
+201840 \\
+200110 \\
+192340 \\
+174830 \\
+153910 \\
+140310 \\
+117460 \\
+108890 \\
+87350\end{array}$ & $\begin{aligned} & 88^{\circ} \cdot 4 \\
&= 43.0 \\
&- 51.0 \\
&- 61.6 \\
&- 68.9 \\
&- 81 \cdot 0 \\
&- 85.8 \\
&- 99.7 \\
&-115.0 \\
&-132.6 \\
&-152.0 \\
&-163.2 \\
&-177.4 \\
&-184.7 \\
&-195.5\end{aligned}$ \\
\hline
\end{tabular}


No. 22.

Antimony-Lead Couple.

One junction at $0^{\circ} \mathrm{C}$; the other at $p t^{\circ}$.

\begin{tabular}{|c|c|c|c|}
\hline $\begin{array}{c}\text { E.M.F. } \\
\text { of Couple } \\
\text { in O.G.S. units. }\end{array}$ & $\begin{array}{l}\text { Temperature } p t^{\circ} \\
\text { in degrees of } \\
\text { StandardPlatinum } \\
\text { Thermometer. }\end{array}$ & $\begin{array}{c}\text { E.M.F. } \\
\text { of Couple } \\
\text { in C.G.S. units. }\end{array}$ & $\begin{array}{l}\text { Temperature } p^{\circ} \\
\text { in degrees of } \\
\text { StandardPlatinum } \\
\text { Thermometer. }\end{array}$ \\
\hline $\begin{array}{r}+31560 \\
+25800 \\
+18920 \\
+13200 \\
+9800 \\
+\quad 6990 \\
+3950 \\
+2790 \\
+1030 \\
-\quad 160 \\
-\quad 760 \\
-\quad 960\end{array}$ & $\begin{array}{r}0 \\
+\quad 98.3 \\
+\quad 88.0 \\
+\quad 74.9 \\
+\quad 60.1 \\
+50.5 \\
+\quad 39.5 \\
+26.6 \\
+20.1 \\
+\quad 8.1 \\
-\quad 5.6 \\
-\quad 17.0 \\
-24.4\end{array}$ & $\begin{array}{r}-\quad 810 \\
-\quad 440 \\
+\quad 110 \\
+\quad 1960 \\
+3180 \\
+6280 \\
+8360 \\
+9970 \\
+10930 \\
+12900 \\
+13990\end{array}$ & $\begin{array}{r}\circ \circ \cdot 3 \\
-\quad 35 \cdot 3 \\
-46 \cdot 9 \\
-60.4 \\
-81 \cdot 8 \\
-96.0 \\
-121 \cdot 7 \\
-140 \cdot 5 \\
-153 \cdot 6 \\
-162.8 \\
-180 \cdot 4 \\
-195 \cdot 7\end{array}$ \\
\hline
\end{tabular}

No. 23.

Aluminium-Lead Couple.

One junction at $0^{\circ} \mathrm{C}$; the other at $p t^{\circ}$.

\begin{tabular}{|c|c|c|c|}
\hline $\begin{array}{c}\text { E.M.F. } \\
\text { of Couple } \\
\text { in C.G.S. units. }\end{array}$ & $\begin{array}{c}\text { Temperature } p t^{\circ} \\
\text { in degrees of } \\
\text { StandardPlatinum } \\
\text { Thermometer. }\end{array}$ & $\begin{array}{c}\text { E.M.F. } \\
\text { of Couple } \\
\text { in C.G.S. units. }\end{array}$ & $\begin{array}{l}\text { Temperature } p t^{\circ} \\
\text { in degrees of } \\
\text { Standard Platinum } \\
\text { Thermometer. }\end{array}$ \\
\hline $\begin{array}{l}-3940 \\
-3650 \\
-3260 \\
-\quad 2990 \\
-2730 \\
-2250 \\
-2070 \\
-1430 \\
-1100 \\
-\quad 560 \\
-\quad 610 \\
-\quad 410 \\
+\quad 380 \\
+1020 \\
+1440\end{array}$ & 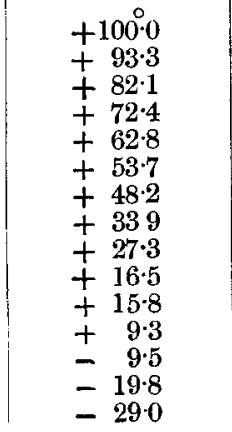 & $\begin{array}{l}+2300 \\
+2690 \\
+\quad 3350 \\
+4040 \\
+5240 \\
+5250 \\
+6520 \\
+7910 \\
+9400 \\
+11360 \\
+12410 \\
+14530 \\
+15150 \\
+17420\end{array}$ & $\begin{array}{r}\quad 39.4 \\
-\quad 49.5 \\
-58.9 \\
-66.2 \\
-81 \cdot 1 \\
-81.8 \\
-96.1 \\
-111.0 \\
-128.6 \\
-148.0 \\
-159 \cdot 2 \\
-175.0 \\
-181.4 \\
-195.5\end{array}$ \\
\hline
\end{tabular}


No. 24

Carbon-Lead Couple.

One junction at $0^{\circ} \mathrm{C}$; the other at $p t^{\circ}$.

\begin{tabular}{|c|c|c|c|}
\hline $\begin{array}{c}\text { E.M.F. } \\
\text { of Couple } \\
\text { in C.G.S. units. }\end{array}$ & $\begin{array}{c}\text { Temperature } p t^{\circ} \\
\text { in degrees of } \\
\text { StandardPlatinum } \\
\text { Thermometer. }\end{array}$ & $\begin{array}{c}\text { EM.F. } \\
\text { of Couple } \\
\text { in C.G.S. units. }\end{array}$ & $\begin{array}{c}\text { Temperature } p t^{\circ} \\
\text { in degrees of } \\
\text { Standard Platinum } \\
\text { Thermometer. }\end{array}$ \\
\hline $\begin{array}{r}+127950 \\
+109830 \\
+97840 \\
+74550 \\
+62110 \\
+46980 \\
+31560 \\
+22690 \\
+10510 \\
-3210 \\
-14630 \\
-23780\end{array}$ & $\begin{array}{r}+98 \cdot 2 \\
+\quad 89 \cdot 9 \\
+77 \cdot 0 \\
+60 \cdot 1 \\
+507 \\
+38 \cdot 9 \\
+263 \\
+\quad 201 \\
+\quad 9 \cdot 0 \\
-\quad 43 \\
-\quad 14 \cdot 7 \\
-23 \cdot 0\end{array}$ & $\begin{array}{r}-34400 \\
-46070 \\
-59360 \\
-77750 \\
-89560 \\
-109880 \\
-122080 \\
-129490 \\
-132770 \\
-141460 \\
-149480\end{array}$ & $\begin{array}{l}-33.3 \\
-\quad 44.9 \\
-586 \\
-79.7 \\
-\quad 98.9 \\
-121.6 \\
-140.6 \\
-152.5 \\
-161.8 \\
-179.4 \\
-196.2\end{array}$ \\
\hline
\end{tabular}

We propose to reserve for a future ccmmunication a full discussion of the iuterpretation of these curves and the bearing of the facts they disclose on the usually accepted thermo-electric theory. Meanwhile it may be sufficient to note that none of these thermo-electric curves are true parabolas over their whole extent. Many of the curves as drawn in the chart in Plate IV. are curves of double curvature, and in some cases point to the existence of more than one neutral point with lead. We propose to convert this chart of electromotive forces into a chart of thermo-electric powers, in which last condition it will lend itself better to a discussion of results. A few remarks may, however, be made respecting the thermo-electromotive force curves shown in the chart. The lines of iron and pianofortesteel, as well as some others, have changes of curvature at certain points which indicate that the thermo-electric lines are broken lines. The line of antimony has two points at which its tangent becomes parallel to the line of lead, indicating that the thermo-electric line of antimony cuts that of lead twice. The bismuth lines are very peculiar. The curves marked Bismuth No. 1 and Bismuth No. 2 are specimens of impure or commercial bismuth; but both these and the enrve of pure bismuth have a sudden break or discontinuity in their course at about $-80^{\circ}$, which we think is not due to errors 
of experiment. These and many other points are receiving consideration, and will be discussed in a subsequent communication. We must, in conclusion, express our great obligations to Mr. D. K. Morris, as well as to Mr. C. Jakeman, for the valuable assistance they have rendered to us in the laborious work of taking and reducing the observations above recorded, as well as in the construction of some of the apparatus used in this research.

VI. Experimental Proof of Van't Hoff's Constant, of Arrhenius's Generalization, and of Ostwald's Law of Dilution in very Dilute Solutions. By Dr. Meyer WILDERMANN *.

\section{Proof of Van't Hoff's Constant.}

TT is well known that it was Van't Hoff who first drew attention to the fact that the equations representing the generalizations arrived at by Boyle, Gay-Lussac, and Avogadro in the case of gases are equally applicable to dissolved substances, if the osmotic pressure of the molecules of the dissolved substance be substituted for the pressure of the gas.

Van't Hoff deduced these laws for solution from thermodynamical considerations-a method which gives them increased validity,-and illustrated them from the osmotic experiments of Pfeffer and de Vries.

At the same time Van't Hoff was able to establish a thermodynamical relation between the osmotic pressure of a dissolved substance and the molecular lowering of vapour-pressure; molecular lowering of freezing-point of the solution thereby furnishing a rational basis for the empirical generalizations of Raoult and of Babo and Wüllner, who had previously investigated the same point.

In Van't Hoff's thermodynamical argument the solutions are assumed to be very dilute, and hence their experimental verification is specially important for the case of very dilute solutions.

The determination of the molecular depression of the freezing-point is the safest and most convenient method of testing the validity of these generalizations, and this has been done for moderately dilute solutions by Van't Hoff himself

* Conmunicated by the Author: read before the British Association on the 13th of August, 1894. 